\title{
Evaluation of caprine arthritis-encephalitis virus transmission in newborn goat kids
}

\section{Estudo da transmissão do vírus da artrite-encefalite caprina em cabritos neonatos}

\author{
Apoliana de Sousa Rodrigues ${ }^{1}$, Raymundo Rizaldo Pinheiro², Roberta Lomonte Lemos de Brito ${ }^{3}$, \\ Leandro Silva Oliveira², Eduardo Luiz de Oliveira ${ }^{2}$, Vanderlan Warlington Souza dos Santos ${ }^{4}$, \\ Alice Andrioli ${ }^{2}$, Thiago Sampaio de Souza ${ }^{5}$, Ronaldo Pereira Dias', Maria Fátima da Silva Teixeira ${ }^{1 *}$
}

\begin{abstract}
Caprine arthritis encephalitis causes considerable losses in goat production. The main form of the caprine arthritis encephalitis virus transmission is through the ingestion of colostrum or milk from infected females. However, some transmissions cannot be explained in this manner. Therefore, this study aimed to evaluate transplacental transmission of caprine arthritis encephalitis virus. Blood samples were collected from 283 newborn kids of Anglo-Nubian and Saanen breeds born from seropositive and seronegative goats. Samples were collected immediately after birth and analyzed with agarose gel immunodiffusion and western blot. All samples were negative in the agarose gel immunodiffusion. However, the western blot test demonstrated that four kids were born positive for caprine arthritis encephalitis virus. This result indicates that although in a low frequency $(1.4 \%)$, there is a possibility of transplacental transmission of small ruminant lentivirus.
\end{abstract}

KEYWORDS: small ruminant lentivirus; agarose gel immunodiffusion; western blot.
RESUMO: A artrite encefalite caprina causa perdas consideráveis para a produção caprina. A principal forma de transmissão do vírus da artrite encefalite caprina é a ingestão de colostro ou leite de fêmeas infectadas. No entanto, algumas transmissóes não podem ser explicadas por esta via. Dessa forma, este estudo teve como objetivo avaliar a transmissão do vírus da artrite encefalite caprina por via transplacentária (vertical). Foram realizadas coletas de sangue em 283 crias recém-nascidas das raças Anglo-Nubiana e Saanen, provenientes de progenitores soropositivos e soronegativos. As amostras foram coletadas logo após o nascimento e analisadas pelas técnicas de imunodifusão em gel de agarose e western blot. No teste de imunodifusão em gel de agarose, nenhum cabrito foi detectado reagente. Porém, no teste de western blot, quatro cabritos nasceram soropositivos. Esse resultado indica que, apesar de baixa frequência $(1,4 \%)$, existe a possibilidade de transmissão via transplacentária do lentivírus de pequenos ruminantes.

PALAVRAS-CHAVE: lentivírus de pequenos ruminantes; imunodifusão em gel de agarose; western blot.

'Faculdade de Veterinária, Universidade Estadual do Ceará (UECE) - Fortaleza (CE), Brazil.

${ }^{2}$ Empresa Brasileira de Pesquisa Agropecuária, Embrapa Caprinos e Ovinos - Sobral (CE), Brazil.

${ }^{3}$ Faculdade de Ciências Agrárias e Veterinárias, Universidade Estadual Paulista “Júlio de Mesquita Filho" (UNESP) - Jaboticabal (SP), Brazil.

${ }^{4}$ Universidade Federal Rural do Semiárido (UFERSA) - Mossoró (RN), Brazil.

${ }^{5}$ Escola de Medicina Veterinária e Zootecnia, Universidade Federal da Bahia (UFBA) - Salvador (BA), Brazil.

*Corresponding author: labovirfavetuece@uece.br

Received on: 07/14/2016. Accepted on: 10/11/2017 


\section{INTRODUCTION}

Caprine arthritis encephalitis (CAE) may decrease the duration of lactation, milk production, and levels of fat and protein in milk produced by infected goats (CARNEIRO, 2011). MARTÍNEZ-NAVALÓN et al. (2013) found that seropositive animals had shorter lactation periods and produced less milk. In addition, such milk presented lower levels of fat, lactose and total solids, as well as higher somatic cell count than the milk produced by seronegative goats.

According to CARNEIRO (2011), this disease promotes predisposal for gastrointestinal parasitic infection by Haemonchus spp. This effect raises the need for worm control medication in up to $60 \%$, especially in primiparous females, with consequent increase in costs and reduction in profitability.

The transmission of CAE virus (CAEV) may occur in a vertical or horizontal manner (BLACKLAWS et al., 2004). The horizontal form of transmission may be intensified in infected flocks if animal concentration is increased, considering that closer contact promotes higher probability of contact with secretions containing infected macrophages or monocytes. Considering that the infection of goat kids occurs through the ingestion of colostrum or milk produced by infected animals, the digestive via is considered the natural form of CAEV transmission (LAMARA et al., 2001) and may occur from goats to sheep (LIMA et al., 2017).

The vertical transmission, either transplacental or intrauterine, has been suggested since the virus was identified in uterine fluid (ANDRIOLI et al., 2007). Pro-viral DNA was also detected in oviduct and ovarian (FIENI et al., 2003) cells from cumulus oophorus (ALI AL AHMAD et al., 2005) in the ovarian cortex, pre-antral follicles (SILVA, 2006), in semen and vaginal duct, which provide the necessary conditions for a possible ingestion of contaminated maternal fluids by the offspring (EAST et al., 1993).

Control measures are based in blocking the virus transmission from infected animals considering the known forms of infection (PINHEIRO et al., 2012). The application of more sensitive diagnostic tests, such as Western blot (WB), provides early detection of seropositive animals, which may be an important tool for control programs (PINHEIRO et al., 2012). Therefore, this study aimed to evaluate the vertical transmission of CAEV.

\section{MATERIAL AND METHODS}

Experimental groups were formed considering the 3 Rs principle, which includes decreasing the number of animals used in scientific research (Conselho Federal de Medicina Veterinária CFMV, resolution N. 879, February 15, 2008), and in accordance with ethical principles adopted by the Conselho Nacional de Controle de Experimentação Animal (CONCEA - Law N. 11.794, October 8, 2008). The Ethical Committee for the Use of Animals of the Universidade Estadual do Vale do Acaraú (CEUA/UVA) approved this study with protocol number 014/12.

Goat kids used in this study were provided by EMBRAPA Sheep and Goats, which possesses a dairy goat flock. The production is in Sobral City, in Ceará semi-arid region, at 3042' South latitude, $40^{\circ} 21^{\prime}$ 'West longitude, and $83 \mathrm{~m}$ altitude. A disease control program is adopted in this flock, in which animals are submitted to gar gel immunodiffusion (AGID), enzyme-linked immunosorbent assay (ELISA) and WB periodically, and based on the results, the seropositive animals are separated from seronegative animals. Goats were divided into groups to provide three parturitions per year in order to prevent intermittence in milk production. Natural mating is controlled in reproduction, in which seronegative nannies were mated with seronegative bucks, while seropositive pairs were formed. Gestation was confirmed after 45 days by means of ultrasound.

For three years, a total of 283 serum samples of newborn goat kids of Anglo-Nubian (166/283) and Saanen (117/283) breeds were collected in parturitions thoroughly inspected, from which 131 were born from seropositive and 152 from seronegative progenitors. Samplings occurred soon after birth and before heated colostrum was ingested.

Blood samples were sent to the Laboratory of Clinical Pathology in EMBRAPA Sheep and Goats. Then, centrifugation was performed at $1,500 \mathrm{xg}$ for 15 minutes, placed in Eppendorf tubes and maintained at $-20^{\circ} \mathrm{C}$ until $\mathrm{AGID}$ and WB were performed.

Tests were performed using antigen derived from secondary culture of caprine synovial membrane cells infected by standard CAEV-Cork strain and prepared according to the methodology by PINHEIRO et al. (2006).

Micro technique of AGID followed the protocol by GOUVEIA et al. (2000). Agarose gel $0.9 \%$ was prepared in phosphate buffered saline and distributed in glass slides. Then, this gel was perforated with standard six-well template cutter and each corresponding well was filled with $30 \mu \mathrm{L}$ of test serum, standard serum, and antigen. To visualize precipitation lines, reading was performed after 48-72 hours with indirect light and dark field. Only second readings were considered definitive.

WB test was performed according to the protocol of RODRIGUES et al. (2014). SDS-PAGE was performed with concentration and separation gels at 4 and $12.5 \%$, respectively. Then, proteins in the gel were transferred to nitrocellulose membranes, which were blocked with PBS Tween at $0.3 \%$. The technique was performed with serum dilutions of 1:50 and conjugated rabbit anti-goat IgG peroxidase (Sigma cat. A5420) dilution of 1:15000. Revelation of protein bands was performed protected from light with substrates 4-Chloro1-Naphthol and 3,3' Diaminobenzidine (DAB), added 30\% $\mathrm{H}_{2} \mathrm{O}_{2}$, and ended with the addition of distilled water. 
All data were tabulated in Excel software and statistically analyzed in the EPI-Info ${ }^{\mathrm{TM}} 7.0$ software.

\section{RESULTS AND DISCUSSION}

From the total of 283 newborn goat kids used in this study, WB detected four Anglo-Nubian seropositive offspring (1.4\% - 4/283), among which three were born from seropositive goats and one from seronegative goats (Table 1). These progenitors were evaluated three times during a four-month interval with $\mathrm{WB}$, indirect enzyme-linked immunosorbent assay (ELISA-I), and AGID.

The infection probably did not occur in the birth canal, considering that blood samples were collected immediately after birth from the newborn goat kids. Therefore, the production of anti-CAEV antibodies indicates these animals were exposed to the virus in the uterine environment. Even if ingestion of infected fluids did occur at birth, antibodies could be produced in time to be identified in the tests. Therefore, this result suggests that transplacental transmission has occurred. DING; XIANG (2009), when analyzing WB through scanner reactions, verified that anti-P28 (gag gene protein - CAEV capsid) antibodies may be detected four days post-infection. This necessary period for the detection of antibodies reinforces the possibility of transplacental transmission.

The findings presented in this study corroborate with KONISHI et al. (2011), who verified that newborn kids separated immediately after birth were positive after two months of age in AGID. These animals were separated from an infected flock and born from positive parents (only buck, nannie or both). BRODIE et al. (1994) suggested that intrauterine transmission of small ruminant lentiviruses might occur in up to $10 \%$ of goat kids born from infected nannie goats, and that high viral titers in the nannies may be an important factor in the uterine transmission.

CROSS et al. (1975) described typical lesions of progressive sheep pneumonia in lambs born from infected sheep through the cesarean section. In addition, CUTLIP et al. (1981) isolated the Maedi-Visna virus from fetuses of seropositive mothers.

LARA et al. (2005) also verified the possibility of CAEV infection through transplacental transmission or at birth of 26 goat kids, which were evaluated with AGID and were born

Table 1. Agarose gel immunodiffusion (AGID) and western blot (WB) tests in newborn goat kids immediately after birth.

\begin{tabular}{|c|c|c|c|c|}
\hline Kid $^{\mathrm{a}}$ & Age & AGID & WB & Progenitors (WB) \\
\hline 1 & \multirow{4}{*}{ Birth $(\mathrm{O} h)$} & - & + & + \\
\hline 2 & & - & + & \multirow{2}{*}{+} \\
\hline 3 & & - & + & \\
\hline 4 & & - & + & - \\
\hline
\end{tabular}

${ }^{\mathrm{a}}$ Goat kids numbers 2 and 3 were born from the same progenitors. from seropositive goat nannies. None of the animals reacted positively for the virus antigen, indicating that the possibility of this vertical transmission is lower than $3.8 \%(1<26)$. In comparison, this study used a higher number of animals (283 goat kids), which were evaluated with two tests, AGID and WB. In addition, AGID test failed to detect seropositive animals, while WB identified $1.4 \%$ of seropositive goat kids, which suggests that AGID is not an adequate test to detect anti-CAEV antibodies in newborn goat kids.

HASEGAWA et al. (2017) used the AGID test associated with ELISA and nested-PCR to evaluate the vertical transmission of goat nannies to the offspring. Five goat nannies infected with CAEV were inseminated with fresh semen obtained from a negative goat buck. Soon after birth, 12 goat kids were separated from progenitors and fed bovine colostrum. These animals were tested with all three diagnostic techniques before colostrum ingestion, 15 days after birth and once per month until one year of age. From the total of 12 , six were positive in the PCR, while none was positive in the serological tests. This study demonstrated that a proper diagnosis must be performed with the association of tests and repetition throughout a long period of time.

ALVAREZ et al. (2005) studied the transmission of Maedi-Visna virus through colostrum of infected sheep and verified that one of the animals separated immediately after birth before colostrum ingestion was seropositive in commercial ELISA test. These authors (ALVAREZ et al., 2006) performed a PCR test in the same animals and found that 13 out of 204 lambs (6.4\%) born from seropositive sheep were positive at birth. In addition, eight of these were positive only in the first collection at zero hours, then negative in all the other periods (15, 30, 90, 180 and 300 days). These results corroborate with the findings in this study, which presented positive animals $(2.2 \%)$ born from seropositive progenitors in WB test before colostrum ingestion.

The placenta of ruminants is syndesmochorial, therefore it presents five membranes between maternal and fetal circulations and the passage of antibodies between them is prevented. However, viral particles may eventually pass through to the fetus, considering that they may be found in the reproductive tract (ANDRIOLI et al., 2002; CAVALCANTE et al., 2013).

ANDRIOLI et al. (2002) made viral isolation followed by nested-PCR and found that CAEV was present in the uterine fluid of positive goat nannies, corroborating with the findings of FIENI et al. (2003), who also identified the presence of this virus in embryo washings.

CAVALCANTE et al. (2013) observed with reverse transcription polimerase chain reaction (RT-PCR) that six goats presented free viral particles in the uterine fluid, demonstrating the potential to transmit this pathogen, which explains the production of antibodies detected by WB in the newborn goat kids in this study.

A possible explanation for the seropositive goat kid born from seronegative progenitors may be that the goat nannie 
was infected. However, factors such as late seroconversion, viral latency, serological latency, and restrict replication may have hindered the presence of antibodies in sufficient quantity for detection in the surveys. However, the virus probably was in the female reproductive tract and was transmitted to the fetus. CUTLIP et al. (1981) isolated MVV from a fetus, which was removed via cesarean section from a seronegative sheep that was in contact with seropositive individuals. CAVALCANTE et al. (2013) studied experimentally 13 female goats inoculated with CAEV-Cork viral strain and all of them were positive in AGID and WB with 30 to 60 days post-infection. After 24 months, all animals presented negative AGID results and only three were positive in WB. In addition, such study also reported that three animals were negative in AGID, ELISA-I, WB and nested-PCR from blood samples. However, these individuals were positive in nested-PCR and/or RT-PCR performed in oocytes and/or uterine fluid samples, demonstrating intermittent seropositive results and that the virus at some point may be found in organs, but not in the blood.

\section{CONCLUSION}

In conclusion, the WB can detect anti-CAEV antibodies in newborn goat kids soon after birth. Vertical transmission of small ruminant lentiviruses exists. In addition, although it occurs in low frequency, this finding has serious repercussions in control programs for these diseases.

\section{ACKNOWLEDGMENTS}

The authors would like to thank the Empresa Brasileira de Pesquisa Agropecuária (EMBRAPA) sheep and goats for providing the technical and structural conditions; Coordenação de Aperfeiçoamento de Pessoal de Nível Superior (CAPES) for providing the scholarship; Conselho Nacional de Desenvolvimento Científico e Tecnológico (CNPq), Fundação Cearense de Apoio ao Desenvolvimento Científico e Tecnológico (FUNCAP) and Banco do Nordeste for their financial support.

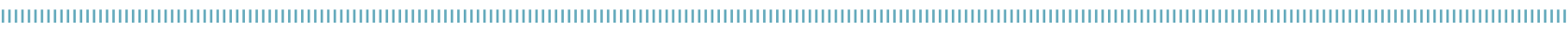
REFERENCES

ALI AL AHMAD, M.Z.; FIENI, F.; MARTIGNAT, L., CHATAGNON, G.; BARIL, G.; BOUVIER, F.; CHEBLOUNE, Y. Proviral DNA of caprine arthritis encephalitis virus (CAEV) is detected in cumulus oophorus cells but not in oocytes from naturally infected goats. Theriogenology, v.64, n.7, p.1656-1666, 2005.

ALVAREZ, V.; ARRANZ, J.; DALTABUIT-TEST, M.; LEGINAGOIKOA, I.; JUSTE, R.A.; AMORENA, B.; DE ANDRÉS, D.; LUJÁN, L.; BADIOLA, J.J.; BERRIATUA, E. Relative contribution of colostrum from Maedi-Visna virus (MVV) infected ewes to MVV seroprevalence in lambs. Research in Veterinary Science, v.78, p.237-243, 2005.

ALVAREZ, V.; DALTABUIT-TEST, M.; ARRANZ, J.; LEGINAGOIKOA, I.; JUSTE, R.A.; AMORENA, B.; DE ANDRÉS, D.; LUJÁN, L.; BADIOLA, J.J.; BERRIATUA, E. PCR detection of colostrum-associated maedi-visna virus (MVV) infection and relationship with ELISAantibody status in lambs. Research in Veterinary Science, v.80, p.226-234, 2006.

ANDRIOLI, A.; GOUVEIA, A.M.G.; MOURA-SOBRINHO, P.A.; PINHEIRO, R.R.; SALLES, H.O. Transferência de embriões em cabras naturalmente infectadas pelo lentivírus caprino. Revista Brasileira de Medicina Veterinária, v.24, p.215-220, 2002.

ANDRIOLI, A.; PINHEIRO, R.R.; GOUVEIA, A.M.G.; SOUZA, K.C., SANTOS, D.O. Controle da Artrite Encefalite Caprina através do uso de tecnologias reprodutivas aplicadas às fêmeas. Documentos. Brasília: Embrapa, 2007. 4p. (Embrapa Caprinos, Comunicado Técnico, 86).

BLACKLAWS, B.A.; BERRIATUA, G.; TORSTEINSPOTTIR, S.; WATT, N.J.; DE ANDRES, D.; KLEIN, D.; HARKISS, G.D. Transmission of small ruminant lentiviruses. Veterinary Microbiology, v.101, p. 199-208, 2004.

BRODIE, S.J.; DE LA CONCHA-BERMEJILLO, A.; KOENIG, G.; SNOWDER, G.D.; DEMARTINI, J.C. Maternal factors associated with prenatal transmission of ovine lentivirus. The Journal of Infectious Diseases, v.169, p.653-657, 1994.

CARNEIRO, F.F.D. Perdas econômicas decorrentes da Artrite-Encefalite Caprina. 97f. Dissertation (Mestrado em Zootecnia) - Universidade Estadual Vale do Acaraú, Sobral, 2011.

CAVALCANTE, F.R.A.; ANDRIOLI, A.; PINHEIRO, R.R.; SOUZA, K.C.; VERAS, A.K.A.; LOPES, T.A.; SOUSA, S.D.; SILVA, P.A.F. Detecção do vírus da Artrite Encefalite Caprina por nested PCR e nested RT-PCR em ovócitos e fluido uterino. Arquivos do Instituto Biológico, São Paulo, v.80, n.4, p.381-386, 2013.

CROSS, R.F.; SMITH, C.K.; MOORHEAD, P.D. Vertical transmission of progressive pneumonia of sheep. American Journal of Veterinary Research, v.36, p.465-468, 1975.

CUTLIP, R.C.; LEHMKUHL, H.D.; JACKSON, T.A. Intrauterine transmission of ovine progressive pneumonia virus. American Journal of Veterinary Research, v.42, p.1795-1797, 1981.

DING, E.Y.; XIANG, W.H. Immune response in goats to caprine arthritisencephalitis virus. Viral Immunology, v.10, p.111-115, 2009.

EAST, N.E.; ROWE, J.D.; DAHLBERG, J.E.; THEILEN, G.H.; PEDERSON, N.C. Modes of transmission of Caprine Arthritis-Encephalitis Virus infection. Small Ruminant Research, v.10, p.251-262, 1993. 
FIENI, F.; ROWE, J.; HOOSEAR, K.; BURUCOA, C.; OPPENHEIM, S.; ANDERSON, G.; MURRAY, J.; BONDURANT, R. Presence of Caprine Arthritis-Encephalitis Virus (CAEV) proviral DNA in genital tract tissues of superovulated dairy goat does. Theriogenology, v.59, p. $1515-1523,2003$.

GOUVEIA, A.M.G.; MELO, L.M.; PIRES, L.L.; PINHEIRO, R.R. Microimunodifusão em Gel de Ágar para o diagnóstico sorológico de infecção por Lentivírus de Pequenos Ruminantes. In: CONGRESSO BRASILEIRO DE MEDICINA VETERINÁRIA, 27., 2000, Águas de Lindoia, SP. Anais... Águas de Lindoia, 2000. p.33.

HASEGAWA, M.Y.; LARA, M.C.C.S.H.; LOBOS, E.M.C.V.; GAETA, N.C.; HAYASHI, M.; SHIRAYAMA, L.; CASTRO, R.C.; GREGORY, L. An experimental study on the vertical transmission of caprine arthritis-encephalitis virus from naturally infected females to their offspring. Small Ruminant Research, v.149, p.23-27, 2017.

KONISHI, M.; NAGURA,Y.; TAKEI, N.; FUJITA, M.; HAYASHI, K.; TSUKIOKA, M.; YAMAMOTO, T.; KAMEYAMA, K.; SENTSUI, H.; MURAKAMI, K. Combined eradication strategy for CAE in a dairy goat farm in Japan. Small Ruminant Research, v.99, p.65-7 1, 2011.

LAMARA, A.; FIENI, F.; MSELLI-LAKHAL, L.; TAINTURIER, D.; CHEBLOUNE, Y. Efficient replication of caprine arthritis-encephalitis virus in goat granulosa cells. Vírus Research, v.79, p. 165-172, 2001.

LARA, M.C.C.S.H.; BIRGEL JÚNIOR, E.H.; BIRGEL, E.H. Possibility of vertical transmission of caprine arthritis-encephalitis virus in neonate kids. Arquivo Brasileiro de Medicina Veterinária e Zootecnia, Belo Horizonte, v.57, n.4, p.553-555, 2005.

LIMA, C.C.V.; AYRES, M.C.C.; PINHEIRO, R.R.; COSTA, J.N.; ANDRIOLI, A.; SOUSA, T.S.; AZEVEDO, D.A.A.; SANTOS, V.W.S.; ARAÚJO,
A.L.M.; PEIXOTO, R.M.; DAMASCENO, E.M.; COSTA NETO, A.O. Caprine lentivirus in sheep milk and sêmen. Arquivo Brasileiro de Medicina Veterinária e Zootecnia, Belo Horizonte, v.69, n.2, p.391-397, 2017.

MARTÍNEZ-NAVALÓN, B.; PERIS, C.; GÓMEZ, E.A.; PERIS, B.; ROCHE, M.L.; CABALLERO, C.; GOYENA, E.; BERRIATUA, E. Quantitative estimation of the impact of caprine arthritis encephalitis virus infection on milk production by dairy goats. The Veterinary Journal, v. 197, n.2, p.311-317, 2013. Available from: <http://www.ncbi. nlm.nih.gov/pubmed/23384438>. Accessed on: Feb. 15, 2013.

PINHEIRO, R.R.; ANDRIOLI, A.; SIDER, L.H.; SANTIAGO, L.B.; OLIVEIRA, E.L.; SOUSA, A.L.M.; ALVES, F.S.F.; CRUZ, J.C.M. Lentiviroses em Pequenos Ruminantes: Principais Métodos de Diagnóstico. Sobral: Embrapa Caprinos e Ovinos, 2012. (Documentos, 107). 42p.

PINHEIRO, R.R.; GOUVEIA, A.M.G.; TORRES, A.M.C.; ANDRIOLI, A.; ALVES, F.S.F. Custo dos antígenos e dos testes de diagnósticos de lentivírus de pequenos ruminantes. Revista Brasileira de Medicina Veterinária, v.28, p.110-113, 2006.

RODRIGUES, A.S.; BRITO, R.L.L.; PINHEIRO, R.R.; DIAS, R.P.; ALVES, S.M.; SOUZA, T.S.; SOUZA, K.C.; AZEVEDO, D.A.A.; ANDRIOLI, A.; MAGALHÃES, D.C.T.; TEIXEIRA, M.F.S. Padronização do Elisa indireto e Western Blot para o diagnóstico da artrite-encefalite caprina. Arquivo Brasileiro de Medicina Veterinária e Zootecnia, v.66, n.2, p.417-424, 2014.

SILVA, J.B.A. Vírus da Artrite Encefalite Caprina (CAEV) em folículos pré-antrais de cabras naturalmente infectadas. 144f. Thesis (Doutorado em Ciências Veterinárias) - Universidade Estadual do Ceará, Fortaleza, 2006. 